\title{
Serological screening for celiac disease in children with colchicine-resistant familial Mediterranean fever
}

\author{
Yasin \$AHIN ${ }^{1}$, Kenan BARUT ${ }^{2}$, Tufan KUTLU'1 , Fugen Cullu COKUGRAS ${ }^{1}$, Amra ADROVIC ${ }^{2}$, Sezgin SAHIN², \\ Tulay ERKAN ${ }^{1}$ and Ozgur KASAPCOPUR ${ }^{2}$
}

\begin{abstract}
Background - Familial Mediterranean fever and celiac disease share some common clinical features such as abdominal pain, diarrhea, arthralgia and arthritis. Also, both of the diseases are associated with many inflammatory and autoimmune diseases. Previous studies have shown the association between familial Mediterranean fever (FMF) and different clinical conditions. Objective - We aimed to investigate the relationship between celiac disease and colchicine-resistant familial Mediterranean fever (crFMF) disease. Methods - This prospective study was conducted at the Department of Pediatric Gastroenterology and Pediatric Rheumatology from October 2015 to August 2016. A total of 24 patients with crFMF were included in the study. We used 60 sex- and age-matched healthy subjects as a control group. Levels of total IgA and tissue transglutaminase (tTG) IgA antibody were measured in both groups. Those with increased level of tTG IgA were tested for anti-endomysium IgA antibodies (EMA). Gastroduodenoscopy and intestinal biopsy were planned for a definite diagnosis of celiac disease in patients with positive EMA. Results - Of the 24 patients in this study, $18(75.0 \%)$ were female. Only $4(16.6 \%)$ of 24 patients were positive for tTG IgA. Patients with positive tTG IgA were then tested for EMA IgA antibodies and none of them had a positive result. Only one (1.6\%) subject from the control group was positive for tTG IgA but EMA positivity was not detected. Conclusion - We did not found celiac disease in 24 children with crFMF. Since crFMF disease is rarely seen in general population, further studies with more patients are needed to provide more precise interpretation.
\end{abstract}

Headings - Celiac disease. Child. Colchicine. Familial Mediterranean fever.

\section{INTRODUCTION}

Familial Mediterranean fever (FMF) is an autosomal recessive disorder characterized by recurrent attacks of fever and serosal inflammation ${ }^{(1)}$.

Familial Mediterranean fever disease is associated with mutation in gene which encodes a protein called "pyrin" localized on chromosome 16. The majority of mutations are missense mutations $^{(2)}$. Pyrin is an inhibitor of inflammatory response. When the mutation occurs in this gene, the inhibitor function diminishes, and the extreme inflammatory episodes come out ${ }^{(3)}$. Attacks of FMF are typically 1-3 days lasting periods of acute synovitis, pleuritis or peritonitis characterized with spontaneous regression of symptoms. The most common finding is abdominal pain in about $90 \%$ of patients $^{(4)}$. The second most common finding is monoarthritis of the lower extremities, commonly seen in about $30 \%$ of patients ${ }^{(4)}$. Attacks occur randomly and the patients are completely healthy between the attacks $^{(2)}$.

Approximately $5 \%-10 \%$ of FMF patients do not respond to colchicine treatment, and the other $5 \%$ can not tolerate this treatment due to side effects ${ }^{(5,6)}$. The mechanism of colchicine resistance is uncertain; it has been suggested that an inadequate colchicine concentration is in mononuclear cells due to the probable genetic defect as unrelated to the underlying FMF disease ${ }^{(7)}$. Colchicine resistancy is defined clinically as the presence of at least one attack per month, despite receiving $2 \mathrm{mg} /$ day or more colchicine treatment ${ }^{(8)}$. IL-1beta blockers and anti-TNF agents are currently recommended for the treatment of patients with crFMF, and are used sporadically ${ }^{(9,10)}$.

Celiac disease $(C D)$ is an immunologically mediated systemic disease caused by gluten and its associated prolamins in genetically susceptible individuals ${ }^{(11)}$. Celiac disease may present with gastrointestinal system symptoms and/or, extraintestinal symptoms as well as without symptoms. Approximately $50 \%$ of celiac patients present with extraintestinal or atypical findings ${ }^{(12)}$.

The cause of variable clinical manifestations of CD is the extent of mucosal injury, gender, age at the disease onset, dietary habits in addition to having both genetic and immunologic pathogenesis of $\mathrm{CD}^{(13)}$

In a recent study including 165 patients with $C D$, it has been reported abdominal pain to be the most commonly seen complaint (seen in $52.7 \%$ of patients), similarly to patients with $\mathrm{FMF}^{(14)}$.

Previous studies have shown the association between FMF and different clinical conditions, including vasculitis, spondyloarthropathies, Behcet disease, inflammatory bowel disease and psoriasis $^{(15,16,17,18,19)}$.

${ }^{1}$ Istanbul University, Cerrahpasa Medical School, Department of Pediatric Gastroenterology, Turkey. ${ }^{2}$ Istanbul University, Cerrahpasa Medical School, Pediatric Rheumatology, Turkey.

This study was conducted at the Department of Pediatric Gastroenterology and Pediatric Rheumatology, Cerrahpasa Medical School, Istanbul University, Turkey.

Corresponding author: Yasin Șahin. E-mail: ysahin977@gmail.com 
Familial Mediterranean fever and CD share some common clinical features such as abdominal pain, diarrhea, arthralgia and arthritis ${ }^{(20)}$. Also, both of the diseases are associated with many inflammatory and autoimmune diseases ${ }^{(21)}$.

There are three studies investigating the frequency of $\mathrm{CD}$ in patients with $\mathrm{FMF}^{(21,22,23)}$. Some authors speculated that intestinal injury in $\mathrm{CD}$ might lead to colchicine malabsorption, and thus underlying celiac disease may explain colchicine intolerance of some FMF patients. But, the normal levels of celiac antibodies titers do not support that hypothesis ${ }^{(20)}$. Because of that, we excluded crFMF patients from our previous study and planned another study for them.

According to our knowledge, there is no study investigating the frequency of $\mathrm{CD}$ in patients with crFMF. It can be difficult to diagnose CD in patients with crFMF because of having similar clinical findings. For this reason, we aimed to investigate the relationship between $\mathrm{CD}$ and crFMF disease.

\section{METHODS}

This prospective cross-sectional study was conducted between October 2015 to August 2016 at the Department of Pediatric Gastroenterology and Pediatric Rheumatology. Twenty four patients with crFMF were included in the study. Patients with coincidental disease, and those who refused to participate to the study were excluded. All patients were diagnosed according to pediatric diagnostic criteria for Familial Mediterranean fever $2009^{(24)}$. All of the patients were followed-up for at least six months. Sixty age- and sex-matched healthy subjects were used as a control group. Also, healthy controls were selected according to similar demographic and socio-economic characteristics to crFMF patients.

The study protocol was approved by the Institutional Ethics Committee (313606 / 06 October 2015). An informed written consent has been obtained from the patients, healthy subjects, and their parents before the study. All patients and controls were evaluated in terms of clinical and laboratory findings of $\mathrm{CD}$. Venous blood samples were taken from all patients and controls. Each sample was divided into aliquots and samples were stored at $-80^{\circ} \mathrm{C}$ until analysis. Immunoturbidometric method was used for determination of total IgA (Roche Diagnostics GmbH, Mannheim, Germany) and ELISA was used for analysis of tissue transglutaminase (tTG) IgA antibody (Catalog No. 3503, Aesku Diagnostics Gmbh, Wendelsheim, Germany). The cut of value of tTG IgA is $12 \mathrm{U} / \mathrm{mL}$. Patients and controls with positive tTG IgA results underwent investigation for EMA IgA (Inova Diagnostics, Inc. Lübeck, Germany) which was performed by IFA technique at the "Duzen Laboratory Group" in Istanbul, Turkey. Gastroduodenoscopy and small intestinal biopsy were planned for patients with positive EMA antibodies in making a definitive diagnosis of the celiac disease.

\section{Statistical analysis}

Statistical Package for Social Sciences for Windows, version 13.0 software (SPSS Inc, Chicago IL, USA) was used for statistical analysis. Frequency, percentage, and mean \pm standard deviation (SD) were used as descriptive statistics. Mann-Whitney U test was used for statistical analysis of two independent groups that had not normally distributed variables. Chi-square test was used for the relationships between categorical variables were analyzed. $P$ value was considered statistically significant as a $<0.05$.

\section{RESULTS}

Of the 24 patients, $18(75.0 \%)$ were female, and $6(25.0 \%)$ were male. The mean age of patients at diagnosis was $6.42 \pm 3.66$ years (TABLE 1). All patients were using colchicine opocalcium $\left(1.2 \mathrm{mg} / \mathrm{m}^{2} /\right.$ day $)$. In addition to that, three patients were using anakinra, two patients steroid, two patients canakinumab, one patient methotrexate, and one patient etanercept. Only $12(50.0 \%)$ of our patients had homozygous M694V mutation. Both homozygous M694V and R202Q mutations were determined in four (16.6\%) patients. Unknown mutations were detected in two patients (TABLE 2).

TABLE 1. Demographic and laboratory characteristics of patients and healthy controls.

\begin{tabular}{lccc}
\hline & $\begin{array}{c}\text { Patients } \\
(\mathbf{n}=\mathbf{2 4})\end{array}$ & $\begin{array}{c}\text { Helthy controls } \\
(\mathbf{n}=6 \mathbf{0})\end{array}$ & \\
\hline & Mean \pm SD & Mean \pm SD & $P$ \\
Age $(\mathrm{yrs})$ & $12.28 \pm 4.79$ & $11.24 \pm 4.79$ & 0.375 \\
Height $(\mathrm{cm})$ & $143.67 \pm 21.09$ & $141.87 \pm 22.32$ & 0.730 \\
Weight $(\mathrm{kg})$ & $41.04 \pm 17.35$ & $39.09 \pm 16.16$ & 0.638 \\
tTG IgA $(\mathrm{U} / \mathrm{mL})$ & $5.52 \pm 9.78$ & $1.89 \pm 2.71$ & 0.015 \\
Total $I g A(\mathrm{mg} / \mathrm{dL})$ & $144.75 \pm 64.46$ & $126.08 \pm 58.12$ & 0.225 \\
Age at diagnosis $(\mathrm{yrs})$ & $6.42 \pm 3.66$ & - & \\
\hline
\end{tabular}

MCV: mean corpuscular volume; Plt: thrombocytes; tTG: tissue transglutaminase.

TABLE 2. FMF gene mutation and laboratory characteristics of patients.

\begin{tabular}{|c|c|c|c|c|}
\hline $\begin{array}{c}\text { Patient } \\
\text { no }\end{array}$ & $\begin{array}{c}\text { tTG-IgA } \\
(\mathrm{U} / \mathrm{mL})\end{array}$ & $\begin{array}{c}\text { Total } \\
\text { IgA } \\
(\mathrm{mg} / \mathrm{dL})\end{array}$ & EMA-IgA & $\begin{array}{c}\text { FMF } \\
\text { gene mutation }\end{array}$ \\
\hline 1 & 40.1 & 103 & - & F4790L/R202Q compound het. \\
\hline 2 & 26.3 & 130 & - & Normal, unknown \\
\hline 3 & 18.3 & 134 & - & M694V homozigot \\
\hline 4 & 14.0 & 296 & - & M694V ve R202Q homozigot \\
\hline 5 & 1.4 & 248 & - & M694V ve R202Q homozigot \\
\hline 6 & 1.2 & 57 & - & Normal, unknown \\
\hline 7 & 0.9 & 43 & - & M694V homozigot \\
\hline 8 & 5.4 & 102 & - & M694V homozigot \\
\hline 9 & 5.4 & 226 & - & M694V homozigot \\
\hline 10 & 1.7 & 179 & - & M694V ve R202Q homozigot \\
\hline 11 & 1.6 & 235 & - & M694V homozigot \\
\hline 12 & 3.0 & 113 & - & M694V homozigot \\
\hline 13 & 3.3 & 202 & - & M694V homozigot \\
\hline 14 & 1.2 & 195 & - & M694V homozigot \\
\hline 15 & 3.0 & 112 & - & $\begin{array}{c}\text { M680I, M694V ve R202Q } \\
\text { mutant }\end{array}$ \\
\hline 16 & 1.0 & 143 & - & M694V homozigot \\
\hline 17 & 0.8 & 154 & - & M694V homozigot \\
\hline 18 & 1.0 & 85 & - & M694I homozigot \\
\hline 19 & 1.0 & 108 & - & E148Q heterozigot \\
\hline 20 & 0.6 & 195 & - & M694V homozigot \\
\hline 21 & 0.6 & 113 & - & M680I/V726A compound het. \\
\hline 22 & 0.5 & 79 & - & R202Qhomozigot, M694V het. \\
\hline 23 & 0.2 & 87 & - & M694V ve R202Q homozigot \\
\hline 24 & 0.1 & 135 & - & M694V homozigot \\
\hline
\end{tabular}

EMA: anti-endomysium antibodies; FMF: familial Mediteranean fever; tTG: tissue transglutaminase. 
Only four $(16.6 \%)$ patients were positive for tTG IgA. Patients with positive tTG IgA were then tested for EMA IgA, and none of them had a positive result. (TABLE 2). Because of that, no gastroduodenoscopy was performed in any of the patients. No IgA deficiency was detected in patient group.

The mean age of control group was $11.24 \pm 4.79$ years. There were $45(75.0 \%)$ female and $15(25.0 \%)$ male in control group. Only one $(1.6 \%)$ subject from control group was positive for tTG IgA, but EMA positivity was not detected. No IgA deficiency was found in control group.

There was a significant difference between patient and control groups in terms of tTG IgA levels $(P<0.05)$ (TABLE 1). However, we did not find $\mathrm{CD}$ in patients with crFMF.

\section{DISCUSSION}

Familial Mediterranean fever disease is commonly seen in different ethnical groups including Turks, Jews, Armenians, Arabs, Italians, Hispanics, and Greeks living around the Mediterranean region ${ }^{(1)}$.

Celiac disease is a chronic immune-mediated enteropathy triggered by gluten intake in genetically susceptible individuals, and is associated with some autoimmune and inflammatory diseases ${ }^{(25)}$. Approximately $30 \%$ of adult celiac patients have one or more autoimmune diseases ${ }^{(26)}$.

The prevalence of $\mathrm{CD}$ is estimated to be $0.5 \%-1 \%$ in different parts of the world except populations having diet rich or poor of gluten ${ }^{(13)}$. Nevertheless, the risk of developing CD is higher in diabetes, autoimmune diseases, and in the relatives of celiac patients because of sharing the same HLA types ${ }^{(13)}$.

The prevelance of $\mathrm{CD}$ has increased dramatically in last 20 years due to the use of serological tests. Only $10 \%$ of celiac patients is symptomatic $^{(27)}$. Even if CD screening is recommended in high risk groups, a majority of asymptomatic cases remains undiagnosed ${ }^{(28)}$.

European Society for Pediatric Gastroenterology, Hepatology, and Nutrition (ESPGHAN) suggests tTG IgA and total IgA tests for initial screening of CD. When tTG IgA positivity is detected, EMA IgA test should be analysed. Gastroduodenoscopy and small intestinal biopsy should be performed in patients with EMA positivity ${ }^{(11)}$. In patients with IgA deficiency, tTG IgG and EMA IgG tests are helpful to make a decision for small intestinal biopsy ${ }^{(28)}$. When used in combination, EMA and tTG antibodies have a specificity and sensitivity of $95 \%{ }^{(29)}$.
Autoinflammatory diseases may resemble or coexist with some autoimmune diseases, therefore it can be difficult to diagnose these diseases $^{(30)}$

There are some case reports on the coexistence of FMF and $\mathrm{CD}^{(31,32,33,34)}$. Also, there are three studies investigating the frequency of $\mathrm{CD}$ in patients with $\mathrm{FMF}^{(21,22,23)}$. There was no relationship between FMF and CD in those mentioned studies. According to our knowledge, there is no study investigating the frequency of CD in patients with crFMF.

Kuloğlu et al. ${ }^{(21)}$ investigated the frequency of $\mathrm{CD}$ in 50 patients with FMF. In this study, no CD was found in any of the patients with FMF. The authors reported that there is no association between FMF and celiac disease.

Işikay et al. ${ }^{(22)}$ investigated the frequency of $\mathrm{CD}$ in 112 patients with FMF and 32 healthy children. Tissue transglutaminase antibody IgA positivity was detected in three patients in FMF group and in one patient in the control group. EMA IgA test was not analysed in those four patients, but gastroduodenoscopy was performed on patients with tTG positive and multiple intestinal biopsies were obtained. Celiac disease was detected in four patients. This study has not shown a relation between FMF and celiac disease compared with the control group.

Our study was carried out according to updated ESPGHAN criteria in 2012. No IgA deficiency was detected. Only four (16.6\%) patients had tTG IgA positivity, then EMA IgA antibody test was analysed, but EMA positivity was not detected in any of them. No gastroduodenoscopy was performed, so CD was not detected in patients group. Also, CD was not detected in control group. Previous studies from Turkey among healthy children between 6-17 years reported a prevalence of celiac disease as a $1 / 212^{(35)}$. None of 24 children with crFMF was diagnosed with $\mathrm{CD}$. We did not find a relationship between $\mathrm{CD}$ and crFMF disease in children.

As a result, no CD was detected in any of 24 patients with crFMF in our study. Because crFMF disease is rarely seen in general population, further studies with more crFMF patients are needed to provide more precise interpretation.

\section{Authors' contribution}

Şahin Y, Sahin S, Barut K, Adrovic A: concept/design, data analysis/interpretation, drafting article, data collection, approval of article. Sahin Y, Cokugras FC, Erkan T, Kutlu T, Kasapcopur O: data analysis/interpretation, critical revision of article, approval of article.

Şahin Y, Barut K, Kutlu T, Cokugras FC, Adrovic A, Sahin S, Erkan T, Kasapcopur O. Triagem sorológica para doença celíaca em crianças com febre familiar do Mediterrâneo colchicina-resistente. Arq Gastroenterol. 2018;55(2):175-8.

RESUMO - Contexto - A febre familiar do Mediterrâneo e a doença celíaca compartilham algumas características clínicas comuns, tais como dor abdominal, diarreia, artralgia e artrite. Além disso, ambas as doenças são associadas a muitas doenças auto-imunes e inflamatórias. Estudos anteriores mostraram associação entre febre familiar do Mediterrâneo e diferentes condições clínicas. Objetivo - Investigar a relação entre doença celíaca e doença de febre familiar do Mediterrâneo colchicina-resistente (FMFcr). Métodos - Foi realizado um estudo prospectivo no departamento de Gastroenterologia pediátrica e Reumatologia pediátrica de outubro de 2015 até agosto de 2016. Um total de 24 pacientes com FMFcr foram incluídos. Sessenta indivíduos saudáveis combinados por sexo e idade foram utilizados como um grupo de controle. Os níveis de IgA total e transglutaminase tissular (tTG) anticorpo IgA foram medidos em ambos os grupos. Aqueles com maior nível de tTG IgA foram testados para anticorpos de IgA antiendomísio (EMA). Gastroduodenoscopia e biópsia intestinal foram planejadas para um diagnóstico definitivo da doença celíaca em pacientes com EMA positivo. Resultados - Dos 24 pacientes neste estudo, 18 (75,0\%) eram do sexo feminino. Somente 4 (16,6\%) de 24 pacientes foram positivos para tTG IgA. Pacientes com tTG IgA positivo então foram testados para anticorpos IgA de EMA, e nenhum deles teve um resultado positivo. Somente um $(1,6 \%)$ indivíduo do grupo controle foi positivo para tTG IgA, mas a positividade EMA não foi detectada. Conclusão - Não encontramos a doença celíaca em 24 crianças com FMFcr. Desde que a doença FMFcr é raramente vista na população em geral, estudos com mais pacientes são necessários para fornecer interpretação mais precisa.

Descritores - Doença celíaca. Criança. Colchicina. Febre familiar do Mediterrâneo. 


\section{REFERENCES}

1. Padeh S, Berkun Y. Familial Mediterranean fever. Curr Opin Rheumatol. 2016;28:523-9

2. Pepper RJ, Kachmann HJ.Autoinflammatory Syndromes in children. Indian J Pediatr. 2016;83:242-7.

3. Booth DR, Gillmore JD, Booth SE, Pepys MB, Hawkins PN. Pyrin/marenostrin mutations in familial Mediterranean fever. QJM. 1998;91:603-6.

4. Federici S, Sormani MP, Ozen S, Lachmann HJ, Amaryan G, Woo P, et al. Evidence-based provisional clinical classification criteria for autoinflammatory periodic fevers. Ann Rheum Dis. 2015;74:799-805.

5. Ben-Zvi I, Livneh A. Colchicine failure in Familial Mediterranean fever and potential alternatives: embarking on the Anakinra trial. Isr Med Assoc J. 2014;16:271-3.

6. Sozeri B, Kasapcopur O. Biological agents in familial Mediterranean fever focusing on colchicine resistance and amyloidosis. Curr Med Chem. 2015;22:1986-91.

7. Lidar M, Scherrmann JM, Shinar Y, Chetrit A, Niel E, Gershoni-Baruch R, et al. Colchicine nonresponsiveness in familial Mediterranean fever: clinical, genetic, pharmacokinetic, and socioeconomic characterization. Semin Arthritis Rheum. 2004;33:273-82.

8. La Regina M, Ben-Chetrit E, Gasparyan AY, Livneh A, Ozdogan H, Manna R. Curren trends in colchicine treatment in familial Mediterranean fever. Clin Exp Rheumatol. 2013;31:41-6.

9. Bilgen SA, Kilic L, Akdogan A, Kiraz S, Kalyoncu U, Karadag O, et al. Effects of antitumor necrosis factor agents for familial Mediterranean fever patients with chronic arthritis and/or sacroiliitis who were resistant to colchicine treatment. J Clin Rheumatol. 2011;17:358-62.

10. Dinarello CA, van der Meer JW. Treating inflammation by blocking interleukin-1 in humans. Semin Immunol. 2013;25:469-84

11. Husby S, Koletzko S, Korponay-Szabo IR, Mearin ML, Phillips A, Shamir R, et al. ESPGHAN guidelines for the diagnosis celiac disease in children and adolescents: an evidence-based approach. J Pediatr Gastroenterol Nutr. 2012;54:136-60.

12. Rampertab SD, Pooran N, Brar P, Singh P, Green PH. Trends in the presentation of celiac disease. Am J Med. 2006;119:355.e9-14.

13. Gujral, N, Freeman HJ, Thomson ABR. Celiac disease: Prevalence, diaggnosis, pathogenesis and treatment. World J Gastroenterol. 2012;18:6036-59.

14. Khatib M, Baker RD, Ly EK, Kozielski R, Baker S. Presenting pattern of pediatric celiac disease. J Pediatr Gastroenterol Nutr. 2016;62:60-3.

15. Barut K, Guler M, Sezen M, Kasapçopur O. Increased frequency of psoriasis in the families of the children with familial Mediterranean fever. Clin Exp Rheumatol. 2016;34:S137.

16. Barut K, Sahin S, Adrovic A, Sinoplu AB, Yucel G, Pamuk G, Aydın AK, Dasdemir S, Turanlı ET, Buyru N, Kasapcopur O. Familal Mediterranean fever in childhood: a single-center experience. Rheumatol Int. 2017 Aug 21.

17. Beser OF, Kasapcopur O, Cokugras FC, Kutlu T, Arsoy N, Erkan T. Association of inflammatory bowel disease with familial Mediterranean fever in Turkish children. J Pediatr Gastroenterol Nutr. 2013;56:498-502.

18. Bodur H, Seckin U, Eser F. Coexistence of familial Mediterranean fever and psoriasis in a patient with seronegative spondyloarthropathy. Rheumatol Int. 2006;26:489-96.
19. Ozdogan H, Arısoy N, Kasapcopur O, Sever L, Caliskan S, Tuzuner N, et al. Vasculitis in familial Mediterranean fever. J Rheumatol. 1997;24,323-7.

20. Mor A, Gal R, Livneh A. Abdominal and digestive system associations of familial Mediterranean fever. Am J Gastroenterol. 2003;98:2594-604.

21. Kuloğlu Z, Ozçakar ZB, Kirsaçlioğlu C, Yüksel S, Kansu A, Girgin N, et al. Is there an association between familial Mediterranean fever and celiac disease? Clin Rheumatol. 2008;27:1135-9.

22. Işikay S, Işikay $\mathrm{N}$, Kocamaz $\mathrm{H}$. The prevalence of celiac disease among patients with familial mediterranean fever. Arq Gastroenterol. 2015;52:55-8.

23. Sahin Y, Kocamaz H, Özen E. Is it a two variable equations?: a rare association of familial Mediterranean fever and celiac disease. The Medical Bulletin of Şişli Etfal Hospital. 2016. doi:10.5350/SEMB.20160401050829.

24. Yalçinkaya F, Ozen S, Ozçakar ZB, Aktay N, Cakar N, Düzova A, et al. A new set of criteria fort he diagnosis of familial Mediterranean fever in childhood. Rheumatology. (Oxford) 2009;48:395-8.

25. Lauret E, Rodrigo L. Celiac disease and autoimmune-associated conditions. Biomed Res Int. 2013;2013:127589.

26. Reilly NR, Green PH. Epidemiology and clinical presentations of celiac disease. Semin Immunopathol. 2012;34:473-8.

27. Garnier-Lengline H, Cerf-Bensussan N, Ruemmele FM. Celiac disease in children. Clin Res Hepatol Gastroenterol. 2015;39:544-51.

28. Murch S, Jenkins H, Auth M, Bremner R, Butt A, France S, et al. BSPGHAN. Join BSPGHAN and Coeliac UK guidelines for the diagnosis and management of coeliac disease in children. Arch Dis Child. 2013;98:806-11.

29. Hill ID. What are the sensitivity and specificity of serologic tests for celiac disease? Do sensitivity and specificity vary in different populations? Gastroenterology 2005;128:S25-32.

30. Kiss MH, Magalhães CS. Autoinflammatory diseases: mimics of autoimmunity or parts of its spectrum? Case presentaton. J Clin Immunol. 2008;28:S84-9.

31. Bas F, Kabataş-Eryılmaz S, Günöz H, Darendeliler F, Küçükemre B, Bundak R, et al . Type 1 diabetes mellitus associated with autoimmune thyroid disease, celiac disease and familial Mediterranean fever: case report. Turk J Pediatr. 2009;51:183-6.

32. Kuloğlu Z, Kansu A, Tutar E, Yalçınkaya F, Ensari A, Girgin N. Association of familia Mediterranean fever and celiac disease in a 14-year-old girl with recurrent arthritis. Clin Exp Rheumatol. 2008;26:S131.

33. Sahin Y, Adrovic A, Barut K, Kutlu T, Cullu-Cokugras F, Sahin S, et al. The frequency of the celiac disease among children with familial Mediterranean fever. Mod Rheumatol. 2017;2:1-11

34. Yilmaz Y, Baran B, Seniz NB, Dolar E. Familial Mediterranean Fever coexisting with celiac disease: is there a link with long-term colchicine treatment? J Gastrointestin Liver Dis. 2009;18:119-20.

35. Dalgic B, Sari S, Basturk B, Ensari A, Egritas O, Bukulmez A, et al. Turkish Celiac Study Group. Prevelance of celiac disease in healthy Turkish school children. Am J Gastroenterol. 2011;106:1512-7. 